\title{
Disaster Management Campaign Via Instagram and Facebook Aksi Cepat Tanggap (Act) Indonesia
}

\author{
Suraya Mansur ${ }^{1}$, Nurhayani Saragih ${ }^{2}$, Rajab Ritonga ${ }^{3}$, Novita Damayanti ${ }^{4}$, Stevie Tri Lestari ${ }^{5}$ \\ Faculty of Communication Sciences University Mercu Buana Jakarta, Faculty of \\ Communication Sciences Universitas Moestopo Beragama Jakarta \\ \{Suraya.suraya@mercubuana.ac.id ${ }^{1}$,nurhayani.saragih@gmail.com², \\ rajab.ritonga@dsn.moestopo.ac.id ${ }^{3}$,novita.damayanti@dsn.moestopo.ac.id ${ }^{4}$, \\ stevietrilestari@gmail.com ${ }^{5}$ \}
}

\begin{abstract}
The focus of this research is to determine the effect of social media contents on the image of "Aksi Cepat Tanggap" (ACT) by using uses and effect theory. The method use is a quantitative survey with questionnaire data collection to followers of ACT's Facebook and Instagram accounts, also supported with related literature. The number of respondents were 100 people each representatively. Research Results: the majority of followers of ACT social media accounts are in the productive age group. The message on ACT's Facebook account is known to affect the image in the public eye by $76.7 \%$, whereas in Instagram's account, the message content affects the image by 83.7\%. The rest, the variables that influence are not examined. In a Facebook account, the message format does not significantly affect ACT's image, while on Instagram, the overall dimensions of the message content affect ACT's image in the public eye.
\end{abstract}

Keywords: Message Content; Action Fast Response (AFR); Social Media; Uses and Effect Theory

\section{Introduction}

Aksi Cepat Tanggap (ACT) is a non-profit organization in the field of social humanity, established in 1994 and inaugurated in 2005. The humanitarian activities carried out by ACT include helping victims of volcanic disasters; assistance with the construction of wells, assistance for sacrificial animals during Eid al-Adha and various other social actions. Various social activities made, ACT's image was quite good in the community.

The image is the emission of the person, company, object, or organization. Someone's perception of the company is based on knowledge about the company [1]. The mass media also tend to have their own choices about what will be reported Dewa Broto [2]. Currently there is a change in how to access information, with high interest in finding information from cyberspace [3]. Kent, Taylor \& White [4] states, web sites not only provide information but also provide public relations for institutions [5].

Social media is able to foster social involvement, namely the ability to maintain relationships and social activities, namely the level of participation in activities in the 
community [6] For corporate reputation [7]. ACT has Facebook, Instagram and You tube. Researchers are interested in examining two ACT social media which are Facebook and Instagram which are examined using the uses and effects theory. On the uses and effects, the need is only one of the factors that cause the use of media. Individual characteristics, expectations and perceptions of the media, and the level of access to media, will bring individuals to the decision to use or not use the media.

The idea of theory uses and gratification mentioned by Sven Windhal (1979), as a synthesis between uses and gratification theory and effect theory. The concept of "use" is point of thought. The knowledge about media usage and the cause, will give a way in understanding and estimating of result from mass communication process [8].

The use of mass media has many meanings, it can mean "exposure" which simply refers to the act of perceiving. In uses and gratification, the use of media is basically determined by individual basic needs. While on the uses and effects, the need is the only one of the factors that cause the use of media. Individual characteristics, expectations and perceptions of the media, and the level of access to media, will bring individuals to the decision to use or not use mass media content.

Social media is a platform that encourage democratization of information, transforming user from content readers to content publishers. This is a shift from the broadcast mechanism to many and to many models. It rooted in conversations among writers, people, and peers. Based on that definition, the fundamental elements of social media are: (1) social media involves various channels and online is the main channel; (2) social media changes rapidly, means that social media continue to evolve; (3) social media is self-participatory. "Audience" is considered creative so they can give comments [9]. Social media for business and performance [10].

The indicators used on this study are based on the opinion of Antony Mayfield which states social media indicators: (1) Participation. Social media encourages contributions and feedback from everyone who is interested; (2) Openness. Almost all social media services are open to feedback and participation. Encourage selection, commenting and various information; (3) Conversations. The communication that occurs is two-way, and can be distributed to the public, of course, through the social media; (4) Community. Communities share the same interests, such as photography, political issues or favorite television and radio programs. Social media provides opportunities for communities to form quickly and communicate effectively; (5) Interconnected. Almost all social media succeed at connecting with each other, making links on sites, other sources and people [11].

The formula of the message will require four problems: (1) what must be said (the message); (2) how to say it (message format); (3) how to deliver it logically (message structure); (4) how to convey it symbolically (message format) and who should say it [12].

The contents of the Message, is what user want to convey, namely concerning the three types of attraction or Unique Selling Proposition (USP) offered to the audience: (a) Rational appeal. Rational attraction emphasizes the benefits of products, such as quality, price, value or performance of products / services; (b) Emotional appeals. The power of emotional dance tries to utilize positive or negative emotions. Such as messages that show love, pride, pleasure, fear, guilt, shame, tension, sadness, and so on; (c) moral appeals. Moral attraction focuses on efforts to encourage consumers to support and participate in various social activities.

Message Structure. How to deliver it logically, is related to: (a) Drawing conclusions. Let the audience conclude their own message read / watched, or companies that confirm the conclusions for the audience; (b) One-sided argument versus two-sided argument. The ad displays one-sided arguments (only shows product strengths but does not show product 
weaknesses) or displays two sides of the product (displays product strengths and weaknesses); (c) Order delivery message. The ad displays the main argument at the beginning of the message or the end of the message, and presents a negative argument and then closes with a positive argument or product superiority.

Message Format. How to convey it symbolically, which involves words, colors, illustrations, pictures / photos, sound quality, headlines, and body language. Message Source. Who should deliver it, especially the credibility of delivering the message. Attractive or popular message sources tend to reach greater attention and memory than ordinary people. Message source credibility is influenced by three factors, namely: (a) Expertise. Specific knowledge possessed by communicators to support and base their claims, for example: doctors; (b) Trustworthiness.

The audience's perception of the objectivity and honesty of the source of the message. Friends and family will be more trusted than strangers or salespeople; (c) Likability describes the attractiveness of the message source, for example popular, beautiful, handsome, humorous, and so on. Companies with a positive image will be more accepted, more desirable and also more supported by various parties who determine the success of the company in achieving various goals and objectives set. A good image is intended so that the organization can continue to develop creativity and can even provide benefits that are more meaningful to others.

According to Rhenald Kasali [13] the impression that arises because understanding of a reality. Understanding itself arises from various sources. One of them is through public opinion, everyone can have different opinions on the same object. And then that opinion can influence public behavior. The company's effort as a source of information on the formation of company image require a complete existence. Complete information is intended as information that can answer the needs and desires of the target object.

According to Shirley Harrison [14], the image of an organization is formed consisting of four elements: (1) Personality, The entire company characteristics that are understood by the target public (knowledge held by the public about the company), such as companies that can be trusted and have social responsibility; (2) Reputation, Reputation is the public perception of organizational actions that have passed and the prospects of the organization in the future, of course compared to similar organizations or competitors. Reputation is related to what company has done and is believed to be the target public based on the experience of both themselves and other parties [15].

According to Charles J. Fombrun, reputation is built by four elements, among others: (a) Credibility Organizations are expected to have credibility in three ways, namely: the organization shows profitability, can maintain stability and have good growth prospects; (b) Reliability This is the expectation of customers or the public, organizations are expected to always maintain quality products or services and guarantee the implementation of excellent service received; (c) Trustworthiness, This is the expectations of employees. The organization is expected to be trusted, the organization can empower employees optimally and the organization can create a sense of belonging and pride for employees; (d) Responsibility. This is the hope of the community. How much or does the organization help the development of the surrounding community, how concerned the organization is to the community and become an environmentally friendly organization; (3) Value: Values held by a company in other words, corporate culture such as the attitude of management who cares about customers, employees who are responsive to customer requests and complaints. 4) Corporate Identity Components that facilitate the introduction of public targets on companies such as logos, colors, and slogans [16]. 


\section{Methods}

This study uses positivistic paradigm with quantitative approach, using questionnaire as data collection method. The type of research is associative research. The variables explain the relationship between message content (X1), message format (X2), message structure (X3), message source (X4) image (Y) of Aksi Cepat Tanggap (ACT) on both Facebook and Instagram social media account.

Number of followers of ACT's Facebook fan page 1,525,616 (https://web.facebook.com/AksiCepatTanggap/ accessed on June 3, 2018) and followers on 264,000 Action Fast Response (@actforhumanity) instagram (https://www.instagram.com / actforhumanity $/ ? \mathrm{hl}=$ en accessed on 3 June 2018). Sampling method used is Purposive Sampling. The number of samples used was 100 respondents. Data collection techniques using a questionnaire as an instrument of data collection. Data analysis was performed by Correlation Analysis (Pearson Product Moment). Correlation shows the direction and strength of the relationship between the variables.

The next step is to do a regression analysis to predict how far the value of the dependent variable changes when the value of the independent variable is manipulated or modified or increased. Simple regression is based on the functional or causal relationship of an independent variable with a dependent variable [17].

First Hypothesis: X1 --- Y: the message content on ACT social media has a significant effect on the image of the organization; second, X2 --- Y: message structure on ACT social media has a significant effect on organizational image; third, X3 --- Y: message format on ACT social media has a significant effect on organizational image; and fourth, X4 --- Y: the message source on ACT's social media has a significant effect on the organization's image.

\section{Result and Discussion}

The composition of social media respondents by sex female respondents from both social media (Facebook and Instagram) are more than male respondents with a percentage of $51 \%$, while male respondents with a percentage of $49 \%$. Facebook respondents are dominated by people aged $26-40$ years with a percentage of $54 \%$, followed by those aged $18-25$ years with a percentage of $30 \%$. Instagram respondents, the age range of respondents between 18-40 years is seen from the table above. For ages 41 and above.

Table 1. Summary Model FB

\begin{tabular}{cccccccccc}
\hline Model & $\mathbf{R}$ & R Square & $\begin{array}{c}\text { Adjusted R } \\
\text { Square }\end{array}$ & $\begin{array}{c}\text { Std. Error of } \\
\text { the Estimate }\end{array}$ & $\begin{array}{c}\text { R Square } \\
\text { Change }\end{array}$ & F Change & df1 & df2 & $\begin{array}{c}\text { Sig. F } \\
\text { Change }\end{array}$ \\
\hline 1 & $.876^{\mathrm{a}}$ & .767 & .758 & 2.511 & .767 & 78.315 & 4 & 5 & .000 \\
\hline
\end{tabular}

a. Predictors: (Constant), X4, X1, X2, X3

From the table above, it can be seen that the $\mathrm{R}$ value (correlation coefficient) shows a value of 0.985 . If included in the equation of the coefficient of determination, the results obtained are:

$\mathrm{Kd}=(\mathrm{R})^{2} \times 100 \%$

$\mathrm{Kd}=(0.876)^{2} \mathrm{X} 100 \%$ 


$$
\mathrm{Kd}=76,7 \%
$$

Based on the data, it can be interpreted that in Facebook, Message Content, Message Structure, Message Format and Message Sources contribute to the ACT Image in the Public Eye at $76.7 \%$. However, there are still $23.3 \%$ of other variables that affect the ACT Image in the Public Eye.

Tabel 2. Model Summary Instagram

\begin{tabular}{cccccccccc}
\hline \multirow{2}{*}{ Model } & R & R Square & $\begin{array}{c}\text { Adjusted } \\
\text { R Square }\end{array}$ & $\begin{array}{c}\text { Std. Error of } \\
\text { the Estimate }\end{array}$ & $\begin{array}{c}\text { R Square } \\
\text { Change }\end{array}$ & F Change & df1 & df2 & $\begin{array}{c}\text { Sig. F } \\
\text { Change }\end{array}$ \\
\hline 1 & $.915^{\text {a }}$ & .837 & .830 & 2.341 & .837 & 121.959 & 4 & 95 & .000 \\
\hline a. Predictors: (Constant), X4, X1, X3, X2 & & & & &
\end{tabular}

From the table above it can be seen that the value of $\mathrm{R}$ (correlation coefficient) shows a value of 0.985 . If entered into the equation of coefficient of determination, the results obtained are:

$\mathrm{Kd}=(\mathrm{R})^{2} \times 100 \%$

$\mathrm{Kd}=(0.915)^{2} \times 100 \%$

$\mathrm{Kd}=83,7 \%$

Message Content, Message Structure, Message Format and Message Sources on Instagram contributed to the ACT Image in the Public Eye which was greater that $83.7 \%$. The rest there are $16.3 \%$ influenced by variables not examined in this study.

Tabel 3. Facebook Multiple Linear Regression Test

\begin{tabular}{|c|c|c|c|c|c|c|}
\hline \multirow{2}{*}{\multicolumn{2}{|c|}{ Model }} & \multicolumn{2}{|c|}{$\begin{array}{l}\text { Unstandardized } \\
\text { Coefficients }\end{array}$} & \multirow{2}{*}{$\begin{array}{c}\begin{array}{c}\text { Standardized } \\
\text { Coefficients }\end{array} \\
\text { Beta }\end{array}$} & \multirow[t]{2}{*}{$\mathbf{t}$} & \multirow[t]{2}{*}{ Sig. } \\
\hline & & B & Std. Error & & & \\
\hline \multirow[t]{5}{*}{1} & (Constant) & 8.400 & 2.669 & & 3.147 & .002 \\
\hline & $\mathrm{X} 1$ & .579 & .163 & .293 & 3.552 & .001 \\
\hline & $\mathrm{X} 2$ & .969 & .306 & .319 & 3.165 & .002 \\
\hline & $\mathrm{X} 3$ & -.014 & .400 & -.004 & -.035 & .972 \\
\hline & $\mathrm{X} 4$ & 1.852 & .536 & .344 & 3.458 & .001 \\
\hline
\end{tabular}

$\mathrm{Y}=\mathrm{a}+\mathrm{bX} 1+\mathrm{bX} 2+\mathrm{bX} 3+\mathrm{bX} 4$

$=8,4+0,579 \mathrm{X}+0,969 \mathrm{X}+(-0,014) \mathrm{X}+1,852 \mathrm{X}$

The results shown on multiple linear regression equation stated: The coefficient of regression value of the Contents Message on Facebook ACT is 0.579 and is positive for the image of the organization in the public eye. The coefficient of the regression value of the Message Structure variable on the ACT Facebook is 0.969 and is positive for the organization's ACT Image in the public eye. The coefficient value of the variable Message Format on Facebook ACT is -0.014 and has a negative value to the image of the organization in the public eye. The coefficient of the regression value of the Message Source variable on the ACT Facebook is 1,852 and has a positive value on the ACT image of the organization in the public eye.

Table 4. Facebook's Simple Linear Regression Test

\begin{tabular}{llccccc}
\hline \multirow{2}{*}{ Model } & \multicolumn{2}{c}{$\begin{array}{c}\text { Unstandardized } \\
\text { Coefficients }\end{array}$} & $\begin{array}{c}\text { Standardized } \\
\text { Coefficients }\end{array}$ & \multirow{2}{*}{ Sig. } & & \\
\cline { 2 - 5 } & B & Std. Error & Beta & & \\
\hline 1 & (Constant) & 2.956 & 2.333 & & 1.267 & .208
\end{tabular}




\begin{tabular}{ccccccc}
\hline \multirow{2}{*}{ Model } & & \multicolumn{2}{c}{$\begin{array}{c}\text { Unstandardized } \\
\text { Coefficients }\end{array}$} & $\begin{array}{c}\text { Standardized } \\
\text { Coefficients }\end{array}$ & t & Sig. \\
\cline { 2 - 5 } & B & Std. Error & Beta & & \\
\hline X1 & .720 & .182 & .326 & 3.955 & .000 \\
X2 & .836 & .258 & .281 & 3.244 & .002 \\
X3 & .675 & .307 & .188 & 2.199 & .030 \\
X4 & 1.023 & .460 & .191 & 2.226 & .028 \\
\hline
\end{tabular}

a. Dependent Variable: Y

$\mathrm{Y}=\mathrm{a}+\mathrm{bX} 1+\mathrm{bX} 2+\mathrm{bX} 3+\mathrm{bX} 4$

$=2,956+0,720 \mathrm{X}+0,836 \mathrm{X}+0,675 \mathrm{X}+1,023 \mathrm{X}$

The results of the simple linear regression equation states: The coefficient of the regression value of the Message Contents variable on Instagram ACT is 0.720 and is positive for the image of the organization in the public eye. The variable structure regression value coefficient Message on Instagram ACT is 0.836 and is positive for the ACT Image organization in the public eye. The regression value coefficient for Message Format variable on Facebook ACT is 0.675 and is positive for the organization's image in the public eye. The regression value coefficient of the Message Source variable on Facebook ACT is 1.023 , which means positive image of the ACT in the public eye.

Table 5. Facebook t test

\begin{tabular}{|c|c|c|c|c|c|}
\hline \multirow[t]{2}{*}{ Model } & \multicolumn{2}{|c|}{$\begin{array}{c}\text { Unstandardized } \\
\text { Coefficients }\end{array}$} & \multirow{2}{*}{$\begin{array}{c}\begin{array}{c}\text { Standardized } \\
\text { Coefficients }\end{array} \\
\text { Beta } \\
\end{array}$} & \multirow[t]{2}{*}{$\mathbf{t}$} & \multirow[t]{2}{*}{ Sig. } \\
\hline & B & Std. Error & & & \\
\hline (Constant) & 8.400 & 2.669 & & 3.147 & .002 \\
\hline $\mathrm{X} 1$ & .579 & .163 & .293 & 3.552 & .001 \\
\hline $\mathrm{X} 2$ & .969 & .306 & .319 & 3.165 & .002 \\
\hline X3 & -.014 & .400 & -.004 & -.035 & .972 \\
\hline $\mathrm{X} 4$ & 1.852 & .536 & .344 & 3.458 & .001 \\
\hline
\end{tabular}

a. Dependent Variable: Y

From the table above it can be seen that: X1 Sig. $0.01<0.05$, which means H0 is rejected and resulted that $\mathrm{H} 1$ is accepted. That is, it can be said that the Variable Message Content does not have a significant effect on ACT Image in the public eye. X2 Sig. $0.02<0.05$, so H0 is rejected and $\mathrm{H} 1$ is accepted. X3 Sig. 0.92>0.05, so H0 is accepted and H1 is rejected. X4 Sig. $0.01<0.05$, so $\mathrm{H} 0$ is rejected and $\mathrm{H} 1$ is accepted.

Tabel 6. Uji t Instagram

\begin{tabular}{lcccccc}
\hline \multirow{2}{*}{ Model } & & \multicolumn{2}{c}{$\begin{array}{c}\text { Unstandardized } \\
\text { Coefficients }\end{array}$} & $\begin{array}{c}\text { Standardized } \\
\text { Coefficients }\end{array}$ & \multirow{2}{*}{ t } & \multirow{2}{*}{ Sig. } \\
\cline { 3 - 5 } & & $\mathrm{B}$ & Std. Error & Beta & & \\
\hline 1 & (Constant) & 2.956 & 2.333 & & 1.267 & .208 \\
& X1 & .720 & .182 & .326 & 3.955 & .000 \\
& X2 & .836 & .258 & .281 & 3.244 & .002 \\
& X3 & .675 & .307 & .188 & 2.199 & .030 \\
& X4 & 1.023 & .460 & .191 & 2.226 & .028 \\
\hline
\end{tabular}

a. Dependent Variable: Y

From the table above it can be seen that: X1 Sig. $0.00<0.05$, which means H0 is rejected and H1 is accepted. X2 Sig. $0.02<0.05$, means H0 is rejected and H1 is accepted. X3 Sig. 
$0.30>0.05$, so H0 is rejected and H1 is accepted. X4 Sig. $0.28<0.05$, which means H0 is rejected and $\mathrm{H} 1$ is accepted.

Table 7. Test the Facebook Hypothesis

\begin{tabular}{ccccccc}
\multicolumn{7}{c}{ ANOVA $^{\mathbf{a}}$} \\
\hline Model & Sum of Squares & df & Mean Square & F & Sig. \\
\hline 1 & Regression & 1975.168 & 4 & 493.792 & 78.315 & $.000^{\mathrm{b}}$ \\
& Residual & 598.992 & 95 & 6.305 & & \\
$\quad$ Total & 2574.160 & 99 & & & \\
\hline
\end{tabular}

a. Dependent Variable: Y

b. Predictors: (Constant), X4, X1, X2, X3

Based on the table above, the significance value is 0,000 , which less than 0.05 , then Ho and $\mathrm{Ha}$ are accepted. The contents, structure, format and source of the message simultaneously influence the ACT image. It can be concluded that the calculated value of X1, X2 and X4 is greater than $\mathrm{t}$ table $(3,552,3,165$ and 3,458) $>1,998$. That is, Message Content, Message Structure and Message Source significantly influence the ACT Image. Whereas X3 is smaller than $\mathrm{t}$ table, i.e. $-0.035<1.998$ shows that $\mathrm{Ho}$ is rejected and $\mathrm{Ha}$ is accepted. This shows that the influence of the Message Format on Facebook does not affect ACT Imagery significantly.

Table 8. Instagram Hypothesis Test

\begin{tabular}{lcccccc}
\hline \multicolumn{7}{c}{ ANOVA $^{\mathbf{a}}$} \\
\hline Model & Sum of Squares & df & Mean Square & F & Sig. \\
\hline Regression & 2674.017 & 4 & 668.504 & 121.959 & $.000^{\mathrm{b}}$ \\
Residual & 520.733 & 95 & 5.481 & & \\
$\quad$ Total & 3194.750 & 99 & & & \\
\hline
\end{tabular}

a. Dependent Variable: Y

b. Predictors: (Constant), X4, X1, X3, X2

Based on the table above, the significance value is 0,000 less than 0.05 , then Ho and Ha are accepted. Then it can be stated that the Content, Structure, Format and Sources of Messages together affect the image of Aksi Cepat Tanggap (ACT). With the results described above, it can be concluded that the value of t count X1, X2, X3 and X4 is greater than t table $(3.955,3.244,2.199$ and 2,226) $>1$,998. That is, Content, Structure, Format and Message Sources significantly affect ACT Image in the public eye.

The probability of the influence of messages delivered via Instagram to the public is higher than Facebook. This is because of the different features available on social media. Namely hashtag on Instagram. This feature makes easy for users to search for specific topics or things with suggestions given by Instagram based on popularity. Another example of the image or video editing feature provided on Instagram is Instagram's advantage compared to Facebook, which requires users to edit their pictures or videos before uploading them.

Based on the results of a simple linear regression test, the message format on Facebook is negative while on Instagram it is positive. This means that the format of the message delivered on Facebook does not always have a positive effect on ACT's image. Message format on Instagram (which consists of Words, Colors, Illustrations, Sound Quality, Headlines, Copy and body language) is able to give positive influence on the image of ACT. Instagram give more strength into brand image and influence public of the ACT's image. ACT followers on social media have the characteristic of a high sense of generosity and social. ACT is considered capable of fulfilling its vision to build a spirit of generosity and to restore faith in 
humanity. This can be seen from the response of ACT followers who showed that they cared and contributed to their participation in humanitarian activities. This is the real effect of using social media in delivering messages to the public. The message that ACT has, both Facebook and Instagram, shows that the probability of its influence on organizational image is quite high. The use of the uses and effect theory in research shows that the results of social media use can have certain effects, one of which is the image of certain organization in the public eye. This result has supporting by research result by Horn et all about Reputation and social media [18] Emeksiz, Gulcin Ipek; Simsek, Ali [19] Dnuta [20] Priambodo [21] Susilo. Anindita; Putra, Reza Kradika [22] Aprinta [23].

\section{Conclusions}

As the calculation on Facebook hypothesis drawn, the value of $t$ arithmetic X1, X2 and X4 is greater than $t$ table $(3.552,3.165$ and 3.458) $>1.998$. That is, the Message Content, Message Structure and Message Source significantly influence the ACT Image in the public eye. Whereas X3 is smaller than t table, i.e. $-0.035<1.998$ shows that Ho is rejected and lead to Ha being accepted. This conclude that the influence of the Message Format on Facebook does not significantly affect ACT Imagery. As for the results of the Instagram hypothesis, the calculated value of X1, X2, X3 and X4 is greater than t table $(3,955,3,244,2,199$ and 2,226)> 1,998. This number lead to conclusion that Message Content, Message Structure, Message Format and Message Source significantly affect ACT image in the public eye.

\section{References}

[1] Ardianto, E. (2011). Research Methodology for Quantitative and Qualitative Public Relations. Bandung: Simbiosa Rekatama Media.

[2] Dewa Broto, G. S. (2014). The PR : Tantangan PublicRelations di Era Keterbukaan Informasi. Jakarta: Gramedia Pustaka Utama.

[3] Brown, Gillian, \& Yule., G. (2009). Analisis Wacana. Jakarta: Gramedia Pustaka Utama.

[4] Kent, M. L., Taylor, M., \& White, W. J. (2003). The Relationship Between Web Site Design and Organizational Responsiveness to Stakeholders.

[5] Park, H., \& Reber, B. H. (2008). Relationship building and the use of Web sites: How Fortune 500 corporations use their Web sites to build relationships. Public Relations Review, 34(4), 409-411.

[6] Bessuk, S., Glass, T., \& Berkman, L. (1999). Social Disengagement and Incident Cognitive Decline in Community-Dwelling Elderly Persons. US: Ann Intern Med.

[7] Dijkmans, Corne; Kerkhof, Peter; Tetik, Asuman Buyukcan; Beukeboom, Camiel J. (2015) Online Conversation and Corporate Reputation: A Two-Wave Longitudinal Study on the Effects of Exposure to the Social Media Activities of a Highly Interactive Company. Journal of Computer -Mediated Communication. Volume 20. International Communication Association. pp. 632-648

[8] Sandjaja, S. D. (2004). Pengantar Ilmu Komunikasi. Jakarta: PT. Raja Grafindo Persada.

[9] Evans, D. (2008). Social Media Marketing: an hour a day. Wiley Publishing Inc.: Indianapolis 
[10] Singh, Tina P.; Sinha, Ratna (2017) The Impact of Social Media on Business Growth and Performance in India. International Journal of Research in Management \& Business Studies (IJRMBS). Vol. 4 Issue Spesial I Januari - Maret 2017. Pp. 36-40

[11] Mayfield, A. 2008. What is social media: an e-book. [Online]. Retrieved from: http://wwww.icrossing.co.uk/What_is_Social_Media_iCrossing_ebook.pdf) [Accessed 31 November 2018].

[12] Kotler, P. (2005). Manajemen Pemasaran Jilid I \& II. Jakarta: PT. Indeks .

[13] Kasali, R. (2003). Manajemen Public Relations: Konsep Dan Aplikasinya Di Indonesia. Jakarta: Pustaka Utama Grafiti.

[14] Harrison, S. (2004). Public Relatin : An Introcudtions. New York: Cengange Learning EMEA.

[15] Fombrun, C. J. and V. P. Rindova (2000). The road to transparency: Reputation management at Royal Dutch Shell. In M. Schultz, M. J. Hatch, \& M. H. Larsen (Eds.), The expressive organization: Linking identity, reputation, and the corporate brand (pp.77-96). Oxford, England, Oxford University Press.

[16] Fombrun, C. J. and V. P. Rindova (2000). The road to transparency: Reputation management at Royal Dutch Shell. In M. Schultz, M. J. Hatch, \& M. H. Larsen (Eds.), The expressive organization: Linking identity, reputation, and the corporate brand (pp.77-96). Oxford, England, Oxford University Press.

[17] Wimmer, Roger D. and Dominick, Joseph (2014) Mass Media Research: An Introduction, Tenth Edition, Wadsworth:Cengage Learning: Amerika

[18] Schulze Horn I., Taros T., Dirkes S, Huer L., Rose M., Tietmeyer R. , Constantinides E., (2015), Business Reputation and Social Media - A Primer on Threats and Responses, IDM Journal of Direct, Data and Digital Marketing Practice, Issue 16, nr .3 http://www.palgrave-journals.com/dddmp/index.html

[19] Emeksiz, Gulcin Ipek; Simsek, Ali. (2018) Communication Strategies Used in Corporate Facebook Pages and Motivations of Consumers for Following These Pages. European Journal of Marketing and Economics. January-April 2018. Volume laki-laki. Issue I.

[20] Szwajca, Danuta. (2017) The Role of Social Media in Corporate Reputation Management-Results The Polish enterprises. Journal Foundation of Management. Sciendo. Volume 9:Issue I. 4 May 2017. Pp. 161-174

[21] R. Kurnia; B. Priambodo (2015) Pengaruh social media terhadap Bisnis E Commerce di Indonesia. Jurnal ilmiah E-Commerce Sistem Informasi. Pp. 8-29

[22] Susilo, Anindita; Putra, Reza Kradika (2019) Membangun Brand Awareness Menggunakan Strategy Cyber PR Pada Perusahaan Start-Up di Indonesia. Jurnal Comunicology. Volume. I:Issue 7. Pp. 34

[23] Aprinta, Gita (2014). Strategi Cyber Public Relations dalam Pembentukan Citra Institusi Pendidikan Tinggi Swasta. Journal THE MESSENGER. Semarang. Volume VI, Nomor I. Edisi Januari 2014. Pp. I-7 